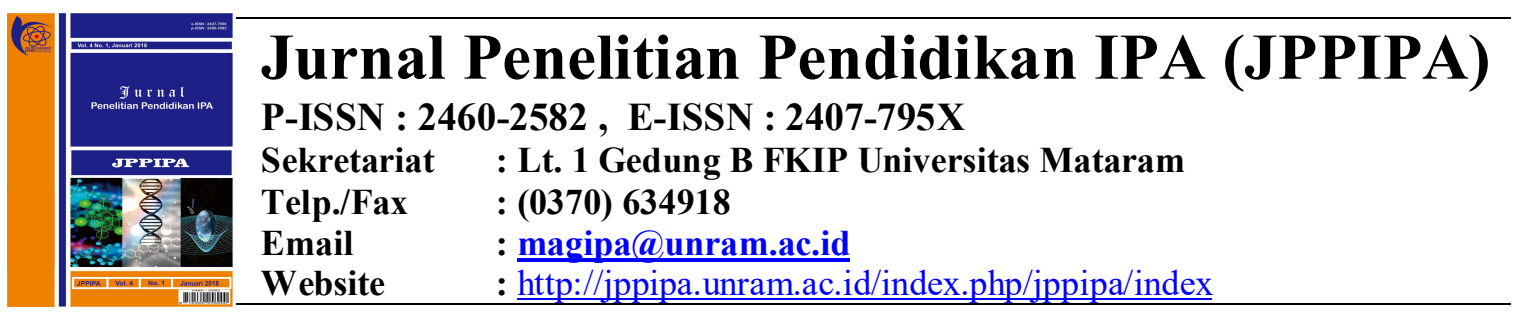

\title{
IDENTIFIKASI SENYAWA TURUNAN HASIL FRAKSINASI KAYU AKAR ARTOCARPUS ODORATISSIMUS
}

\author{
Putri Ayu Mutmainnah ${ }^{1}$, Aliefman Hakim ${ }^{2}$, L. Rudyat Telly Savalas ${ }^{3}$ \\ Program Studi Magister Pendidikan IPA, Program Pascasarjana Universitas Mataram ${ }^{123}$ \\ Email:putriayu_mutmainnah83@yahoo.com
}

\begin{tabular}{|c|c|}
\hline Key Words & Abstract \\
\hline $\begin{array}{l}\text { Artocarpus } \\
\text { odoratissimu } \\
\text { s, phenyl } \\
\text { prophane }\end{array}$ & $\begin{array}{l}\text { This research has made for identification derivate compound of } \\
\text { fractionation derivate compound of fractionation root bark Artocarpus } \\
\text { ododratissimus. Root bark A. dodoratissimus has macerated by } \\
\text { methanol. Fractionation by using Vacuum Liquid Choromatography } \\
\text { with eluen variation from nonpolar till polar (n-hexane 100\%; n- } \\
\text { hexane:ethyl acetate 9:1 till 1:9; ethyl acetate 100\% and ethyl } \\
\text { acetate:methanol 9,5:0,5 and 9:1) produce main fraction. Purified by } \\
\text { used with Gravitation Coulumb Chomatograph produce seven main } \\
\text { fraction. Identification based on FT-IR and }{ }^{1} H \text {-NMR showed that the } \\
\text { pure compound assumed phenyl prophane derivation. }\end{array}$ \\
\hline Kata Kunci & Abstrak \\
\hline $\begin{array}{l}\text { Artocarpus } \\
\text { odoratissimus, } \\
\text { fenil } \\
\text { propanoid }\end{array}$ & $\begin{array}{l}\text { Penelitian ini bertujuan untuk mengidentifikasi senyawa turunan hasil } \\
\text { fraksinasi kayu akar Artocarpus odoratissimus. Kayu akar } A \text {. } \\
\text { odoratissimus dimaserasi dengan pelarut metanol. Fraksinasi dilakukan } \\
\text { menggunakan Kromatografi Cair Vakum (KCV) dengan variasi eluen } \\
\text { mulai dari nonpolar sampai polar ( } n \text {-heksan } 100 \% \text {; } n \text {-heksan : etil asetat } \\
=9: 1 \text { sampai } 1: 9 \text {; etil asetat } 100 \% \text {, dan etil asetat: metanol 9,5:0,5 dan } \\
\text { 9:1) menghasilkan } 10 \text { fraksi utama. Pemurnian dilakukan dengan } \\
\text { kromatografi kolom grafitasi menghasilkan } 7 \text { fraksi utama. Hasil } \\
\text { identifikasi berdasarkan FT-IR dan }{ }^{1} \text { H-NMR menunjukan bahwa } \\
\text { senyawa murni tersebut diduga senyawa turunan fenilpropanoid }\end{array}$ \\
\hline
\end{tabular}

PENDAHULUAN

Artocarpus merupakan tanaman yang tumbuh di hutan tropis yang berpotensi sebagai sumber bahan kimia bioaktif. Tanaman famili Moraceae ini terdiri dari 60 genus yang meliputi 1400 spesies. Di Indonesia khususnya memiliki 20 spesies tumbuhan dari 17 genus Moraceae (Heyne, 1987). Terdapat tiga genus yang memiliki jumlah spesies yang besar, yaitu Artocarpus, Ficus dan Morus.
Genus yang memiliki keanekaragaman terbesar dii Indonesia adalah genus Artocarpus. Terdapat 2 spesies utama yaitu Artocarpus altilis (sukun) dan Artocarpus heterophyllus (nangka) (Kochummen, 2000). Berdasarkan hasil studi literatur, spesies dari Artocarpus telah menghasilkan sejumlah senyawa metabolit sekunder seperti terpenoid, flavonoid, stilbenoid, arilbenzofuran, 
neolignan, dan adduct Diels-Alder. Kelompok flavonoid merupakan senyawa paling banyak ditemukan dari tumbuhan Artocarpus (Hakim, 2010). Beberapa senyawa yang dihasilkan oleh spesies Artocarpus memberikan efek fisiologis seperti antibakteri (Darmawati et al., 2015), antituberkulosis (Boonphong et al., 2007), antimalaria (Widyawaruyanti et al., 2007; Hakim et al., 2011), antikanker ( Ko et al., 2005; Hsu et al., 2011; Risdian et al., 2014; Tantengco et al., 20015), antidiabetes (Nasution, 2013), antimikroba (Teanpaisan et al., 2014), antioksidan (Bakar et al., 2009; Akanni et al., 2014), antiplatelet (Weng et al., 2006), antiinflamasi (Wang et al., 2008).

Flavonoid disintesis melalui dua jalur metabolis, jalur asam skhikimat dan jalur poliketida. Jalur asam skhikimat menghasilkan senyawa fenil propanoid yang berfungsi sebagai senyawa stater pada jalur poliketida (Raharjo, 2012).

Potensi yang besar terhadap kandungan senyawa metabolit sekunder khususnya flavonoid yang terdapat pada golongan Artocarpus membuka peluang baru dalam penelitian. Beberapa spesies tumbuhan Artocarpus yang telah diteliti antara lain $A$. heterophyllus dan $A$. champedan yang kesemua bagiannya sudah dilaporkan. Penemuan ini mengindikasikan bahwa pada genus yang sama berpotensi sebagai sumber flavonoid atau senyawa metabolit sekunder lainnya.

Penelitian tentang tanaman $A$. odoratissimus sangat menarik mengingat baru sebagian dari tanaman ini yang telah dilaporkan. Bagian tanaman $A$. odoratissimus yang telah dilaporkan yaitu daun (Tasmin et al., 2014), kayu dan kulit batang (Hakim et al., 2011), biji dan daging buah (Bakar et al., 2009) sedangkan kayu akar A. odoratissimus belum pernah dilaporkan.

\section{METODOLOGI \\ Bahan}

Bahan tumbuhan berupa kayu akar $A$. odoratisssimus dikumpulkan dari taman
Hutan sesaot, Lombok Barat. Bahan dicacah menyerupai serbuk, kemudian dikering anginkan selama 1 minggu. Bahan lain yaitu pelarut-pelarut teknis dan pure analis seperti n-heksan (p.a), etil asetat (p.a), metanol (teknis), dan Dichloromethan (p.a). Serium sulfat1,5\% dalam asam sulfat $2 \mathrm{~N}$ sebagai penampak noda. Kapas, kertas saring whatman, alumunium foil, plat KLT silica gel Merck 60 F254 0,25 mm ukuran 20x20 cm dengan aluminium sebagai penyangga fasa diam. Silika gel Merck 60 G ukuran 200 mesh untuk kromatografi cair vakum, dan silika gel Merck 60 (35-70 mesh) untuk kromatografi kolom.

\section{Alat yang digunakan}

Peralatan yang digunakan terdiri dari penguap putar vacum (rotary evaporator), Erlenmeyer, gelas kimia, gelas ukur, pipa kapiler, pipet tetes, spatula, bejana pengembang (chamber), wadah maserasi, , botol vial, peralatan kromatografi cair vakum (KCV), kromatografi kolom grafitasi (KKG), kromatografi lapis tipis (KLT).

\section{Cara Kerja}

Penelitian yang dilakukan ini terdiri dari beberapa tahap yaitu tahap ekstraksi, pemisahan dan pemurnian dengan berbagai teknik kromatografi. Kemurnian senyawa hasil isolasi ditetapkan berdasarkan analisis KLT.

\section{Kromatografi Lapis Tipis (KLT)}

Pemisahan dengan KLT digunakan untuk mencari fase gerak terbaik yang akan digunakan dalam kromatografi kolom. Fraksi ditotolkan pada plat KLT dengan menggunakan pipa kapiler. Setelah kering lalu dimasukan kedalam bejana. Bila fasa gerak mencapai batas yang ditentukan, plat diangkat dan dikeringkan diudara terbuka. Noda yang terbentuk diamati pada lampu UV 254nm dan 366 nm. Selain itu, KLT juga digunakan untuk menentukan pola noda. Apabiloa noda yang tampak pada lampu UV sama, maka dilakukan penggabungan sehingga dapat menyederhanakan isolat yang diperoleh. 


\section{Kromatografi Kolom Cair Vakum (KCV)}

KCV bertujuan untuk memisahkan senyawa-senyawa didalam ekstrak. Sampel tersebut bermigrasi terhadap fasa diam dan fasa gerak dengan cepat karena berada dalam suasana vakum (Oktaviani et al., 2015). Prinsip kerja KVC yaitu partisi dan adsorpsi komponen senyawa yang pemisahannya dibantu dengan tekanan dari alat vakum (Maro et al., 2015). Fasa diam yang digunakan dalam kromatografi kolom cair vakum adalah silika gel G60 ukuran \pm 200 mesh, sedangkan fasa geraknya digunakan fasa gerak terbaik pada KLT dengan eluen n-heksan 1005, nheksana : etil asetat, etil asetat $100 \%$ dan etil asetat : metanol.

Corong yang diletakkan diatas kolom $\mathrm{KCV}$ yang berdiameter $13 \mathrm{~cm}$ dan tinggi $24 \mathrm{~cm}$ diisi dengan fasa diam silika gel 60 $\mathrm{GF}_{254}$ dengan ketinggian silika mencapai lebih kurang $4 \mathrm{~cm}$. Kedalam kolom dimasukan kedalam gel yang dikemas dalam keadaan kering, lalu dibagian atas ditutup dengan kertas saring. Alat vakum dihidupkan untuk memperoleh kerapatan yang maksimum. Sebelum dilakukan proses pemisahan dengan kolom kromatografi vakum, sampel diimpregnasi terlebih dahulu menggunakan silica gel dengan ukuran 50-100 mesh. Sevbanyak $12 \mathrm{~g}$ ekstrak methanol diimpreknasi dengan silica gel sebanyak 6 g kemudian digerus hingga homogen dan kering $(17,1$ g). selanjutnya sampel dimasukan pada bagian atas kolom yang disebar secara merata lalu diletakan kertas saring diatasnya. Kemudian dielusi mulai dari kepolaran rendah lalu kepolaran ditingkatkan perlahan-lahan dan kolom dihisap sampai kering pada setiap pengumpulan fraksi (Hostettmann et al., 1995).

\section{Kromatografi Kolom Gravitasi (KKG)}

Senyawa hasil KCV dimurnikan dengan menggunakan kromatografi kolom gravitasi (KKG). Pemurnian senyawa dengan KKG memanfaatkan sifat kepolaran senyawa dan gaya gravitasi.
Pemisahan dengan kromatografi kolom gravitasi biasanya akan memperoleh hasil yang baik apabila digunakan campuran pelarut yang dapat memisahkan komponen Rf kurang dari 0,3 pada uji coba dengan KLT (Atun, 2014).

\section{HASIL DAN PEMBAHASAN Ekstraksi Sampel}

Sebanyak 1,5 kg serbuk kayu akar $A$. odoratissimus yang telah kering dihaluskan kemudian dimaserasi dengan pelarut metanol didiamkan selama $3 \times 24$ jam pada suhu kamar $\left(25^{\circ} \mathrm{C}\right)$. Filtrat hasil maserasi kemudian dilakukan penyaringan menggunakan corong buchner. Filtrat yang diperoleh kemudian dikeringkan dengan menggunakan rotary evaporator sehingga diperoleh ekstrak metanol berupa padatan berwarna coklat kehitaman sebanyak 28,1 gr.

Pemilihan metode maserasi dalam ekstraksi dikarenakan proses yang mudah dan sederhana. Prinsip ini didasarkan pada distribusi zat terlarut dengan perbandinagn tertentu antara dua pelarut yang tidak saling bercampur (Tasmin et al., 2014).

Metanol dipilih sebagai pelarut karena metanol merupakan pelarut yang dapat melisiskan membran sel pada tanaman dan memiliki struktur molekul yang kecil sehingga mampu menembus jaringan tumbuhan untuk menarik senyawa aktif keluar (Tasmin et al., 2014). Metanol juga memiliki kelebihan yaitu memiliki titik didih yang lebih rendah sehingga mudah diuapkan pada suhu yang lebih rendah (Atun, 2014).

Pada proses maserasi pelarut metanol akan masuk ke rongga sel menembus dinding sel kayu akar A. odoratissimus melarutkan zat aktif yang ada dalam sel sehingga konsentrasi yang tinggi terbentuk dibagian dalam kayu akar $A$. odoratissimus. Karena perbedaan konsentrasi zat aktif didalam dan diluar sel menyebabkan terjadinya difusi zat aktif yang ada dalam sel akan keluar sel. 


\section{Kromatografi Lapis tipis}

Kromatografi lapis tipis (KLT) adalah suatu teknik pemisahan komponenkomponenn campuran suatu senyawa yang melibatkan partisi suatu senyawa diantara padatan penyerap (adsorben, fasa diam) yang dilapiskan pada pelat kaca atau alumunium dengan suatu pelarut (fasa gerak) yang mengalir melewati adsorben (padatan penyerap) (Atun, 2014).

Ekstrak kental hasil maserasi di KLT menggunakan campuran pelarut DCM : metanol $(9,5: 0,5)$. Pada kromatogram menunjukan adanya 3 spot yang terbentuk dengan Rf masing-masing 0,16, 0,3, dan 0,54 . Selanjutnya campuran pelarut tersebut digunakan sebagai eluen pada $\mathrm{KCV}$. pola noda pada kromatogram dapat dilihat pada Gambar 1.

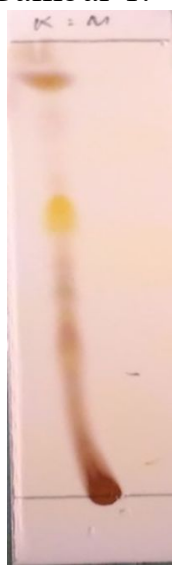

Gambar 1. Kromatogram hasil KLT ekstrak total.

Pada kromatogram setelah disemprot dengan serium sulfat terlihat ada 3 noda yang terbentuk dengan beberapa pengotor. Dari warna yang ditunjukan masingmasing berwarna gelap diduga senyawa turunan fenilpropanoid, dan kuning diduga senyawa golongan flavonoid.

\section{Kromatografi Cair Vakum}

Ekstrak metanol difraksinasi dengan metode kolom cair vakum dengan berbagai pelarut. Tahap fraksinasi ini digunakan eluen $\mathrm{n}$-heksan $100 \%(2 \mathrm{x})$, campuran $\mathrm{n}$ heksana:etil asetat dengan berbagai perbandingan yaitu 9:1 (2x), 8:2 (2x), 7:3 $(2 x), 6: 4(2 x), 1: 1(2 x), 4: 6(2 x), 3: 7(2 x)$, $2: 8(2 x), 1: 9(2 x)$, etil asetat $100 \%(4 x)$, dan etil asetat:methanol 9,5:0,5 (4x), 9:1 $(4 \mathrm{x})$.

Dari hasil KCV diperoleh sebanyak 13 fraksi yang selanjutnya fraksi-fraksi tersebut dianalisis menggunakan KLT. Noda-noda dengan Rf yang sama pada pelat KLT selanjutnya digabung sehingga menghasilkan 10 fraksi utama yaitu fraksi A (70,3 mg), B (79mg), C (102mg), D (210mg), E (420,3mg), F (470mg), G (1,21 g), H ( $500 \mathrm{mg}$ ), I (521 mg) dan J (457 mg). fasa gerak yang digunakan adalah DCM : n-heksana $(6: 4)$ untuk hasil KCV. Hal ini dikarenakan noda memberikan pola pemisahan yang cukup baik yang terlihat pada Gambar 2.

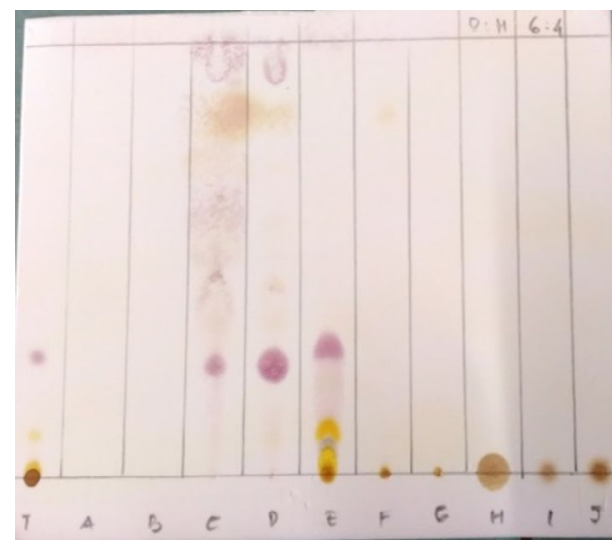

Gambar 2. Kromatogram fraksinasi ekstrak metanol.

Golongan senyawa pada hasil fraksinasi diidentifikasi secara kualitatif menggunakan serium sulfat. Hasil KLT menunjukan pada fraksi $\mathrm{D}$ terdapat 1 noda besar dengan sedikit pengotor berwarna ungu diduga senyawa ini termasuk senyawa turunan fenilpropanoi. Sedangkan pada fraksi $\mathrm{E}$ terdapat noda berwarna ungu dan kuning, diduga pada fraksi ini terdapat dua senyawa golongan fenilpropan dan flavonoid.

\section{Pemurnian senyawa kimia}

Terhadap fraksi D (220 mg) dilakukan fraksinasi dengan kromatografi kolom grafitasi dengan eluen DCM: n-heksan (1 : 1) menghasilkan 7 fraksi utama $A 1, A 2$, A3, A4, A5, A6 dan A7. Selanjutnya fraksi-fraksi ini di KLT untuk melihat pola 
noda yang terbentuk. Kromatogram hasil KKG dapat dilihat pada Gambar 3.

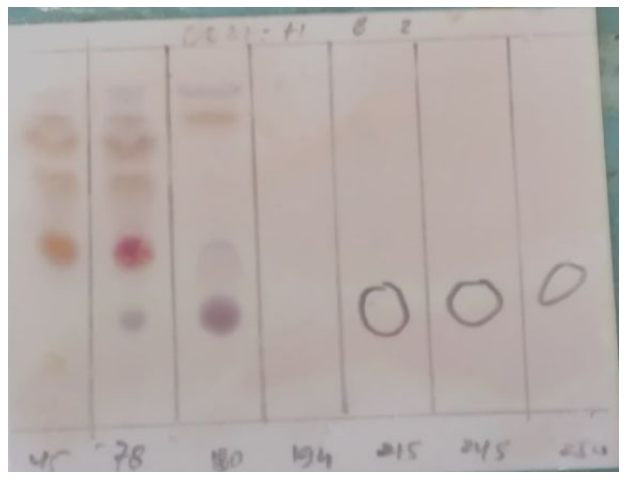

$\mathbf{A}_{1}$

$\begin{array}{llllll}\mathbf{A}_{2} & \mathbf{A}_{3} & \mathbf{A}_{4} & \mathbf{A}_{5} & \mathbf{A}_{6} & \mathbf{A}_{7}\end{array}$

Gambar 3. Kromatogram hasil KKG.

Dari kromatogram terlihat bahwa fraksi A5-A7 memiliki noda tunggal. Selanjutnya fraksi-fraksi tersebut disatukan dan diuji kemurniannya menggunakan tiga variasi pelarut yaitu DCM $100 \%$, DCM : $n$-heksana $(8: 2)$ dan Kloroform : $n$-heksana (6 : 4). Kromatogram hasil uji kemurnian dapat dilihat pada Gambar 4.

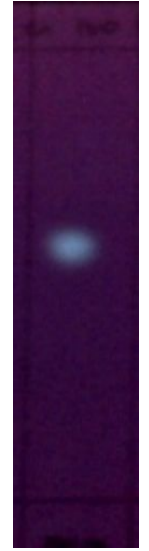

a

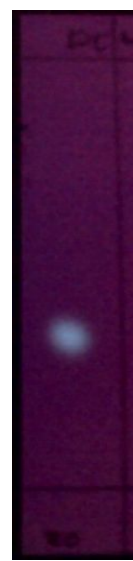

b

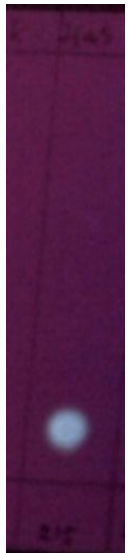

c
Gambar 4. Kromatogram hasil uji kemurnian dengan tiga fariasi eluen.

Dari kromatogram terlihat noda tunggal berwarna biru (UV 366), secara KLT dapat dikatakan bahwa senyawa tersebut telah murni dan dapat ditentukan struktur senyawanya.

\section{Identifikasi Fraksi A dengan spektrofotometri FT-IR}

Data bilangan gelombang dan kemungkinan gugus fungsi dapat dilihat pada Tabel 1.

Tabel 1. Data FT-IR senyawa hasil isolasi

\begin{tabular}{|c|c|}
\hline Bialngan gelombang $\left(\mathrm{cm}^{-1}\right)$ & Kemungkinan gugus \\
\hline Pustaka & \\
\hline $350-3200$ & Melebar \\
\hline 2956,$8 ; 2924,1 ; 2854,6$ & $\mathrm{CH}$ aromatic \\
\hline $1850-1730$ & Tajam \\
\hline 1602,$8 ; 1462,0$ & $\mathrm{C}=\mathrm{C}$ aromatic \\
\hline $1475-1300$ & $\mathrm{CH}$ alifatik \\
\hline 1282,$6 ; 1124,5 ; 1074,3 ; 1039,3$ & C-O alcohol \\
\hline $\begin{array}{ll}742,5 ; 704,0 & 900-700 \\
\end{array}$ & $\mathrm{CH}$ aromatic \\
\hline $\begin{array}{l}\text { Hasil spektrum IR dari fraksi A } \\
\text { menunjukan bahwa pada isolat } \\
\text { mengandung beberapa gugus fungsi, } \\
\text { diantaranya gugus OH yang muncul pada } \\
\text { bilangan gelombang } 3446,7 \mathrm{~cm}^{-1} \text {. Gugus } \\
\mathrm{CH} \text { aromatik ditunjukan dengan adanya } \\
\text { serapan pada bilangan gelombang } 2956,8 \text {; } \\
2924,1 ; 2854,6 \mathrm{~cm}^{-1} \text { yang diperkuat }\end{array}$ & $\begin{array}{l}\text { aromatik ditunjukan dengan adanya } \\
\text { serapan pada bilangan gelombang } 1602,8 \text {; } \\
1462,0 \mathrm{~cm}^{-1} \text {. Gugus karbonil atau keto } \\
(\mathrm{C}=\mathrm{O}) \text { pada senyawa ini ditunjukan } \\
\text { dengan adanya serapan berintensitas kuat } \\
\text { dan bentuk pita tajam pada bilangan } \\
\text { gelombang } 1730,1 \mathrm{~cm}^{-1} \text {. }\end{array}$ \\
\hline $\begin{array}{l}\text { dengan adanya serapan pada daerah } 742,5 \\
\text { dan } 704,0 \mathrm{~cm}^{-1} \text {. Selain terdapat } \mathrm{CH}- \\
\text { aromatik, juga terdapat serapan } \mathrm{C}=\mathrm{C} \\
\text { aromatik yang menandakan cincin }\end{array}$ & $\begin{array}{l}\text { Data } 1 \mathrm{H} \text { NMR menunjukan adanya } \\
\text { dua sinyal pada daerah aromatik } 7,7-7,5 \\
\text { ppm dengan multiplisitas doblet }(7,7 \mathrm{ppm}) \\
\text { dan triplet }(7,5 \mathrm{ppm}) \text {. Sinyal pada daerah }\end{array}$ \\
\hline
\end{tabular}


4,3 dengan multiplisitas multiplet yang merupakan gugus alkana.

Adanya sinyal-sinyal pada daerah aromatik dengan multiplisitas doblet dan triplet diduga bahwa sinyal-sinyal tersebut berasal dari unit benzena yang merupakan kerangka dasar dari senyawa fenil propanoid. Gugus lain adalah gugus alkena yang muncul sebagai triplet, gugus ini diduga berasal dari rantai samping pada senyawa fenil propanoid. Tidak terlihatnya gugus-gusus yang lain dikarenakan pada senyawa ini masih terdapat senyawasenyawa pengotor.

Artocarpus terkenal dengan kandungan senyawa flavonoid. flavonoid disusun oleh fenil propanoid dan poliketida. Dari gugus fungsi hasil spektrum IR dan 1H-NMR diperkirakan bahwa senyawa ini merupakan kerangka struktur dari senyawa turuna fenil propanoid.

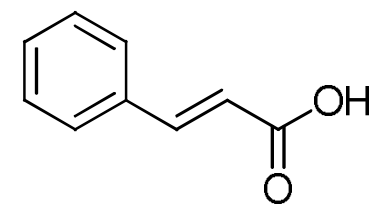

Gambar 5. Senyawa turunan fenil propanoid

\section{KESIMPULAN}

Dari kayu akar A.odoratissimus telah berhasil dimurnikan senyawa yang diduga senyawa turunan fenil propanoid. Identifikasi dengan data FT-IR dan $1 \mathrm{H}-$ NMR diduga senyawa ini merupakan senyawa turunan fenil propan.

\section{SARAN}

Perlu dilakukan kajian lebih mendalam tentang struktur senyawa hasil isolasi menggunakan analisis NMR dua dimensi untuk mengetahui struktur senyawa tersebut.

\section{DAFTAR PUSTAKA}

Bakar, M, F, A., Maryati, M., Asmah, R., dan Jeffrey, F. 2009. Phytochemicals and antioxidant activity of different parts of bambangan (Mangifera pajang) and tarap (Artocarpus odoraissimus). Food Chemistry 113-134

Boonphong, S., Baramee, A., Kittakoop, P., Puangsombat, P. 2007. Antitubercular and antiplasmodial prenylated flavones from the roots of Artocarpus altilis. Chiang Mai journal of science 34, 339-344

Darmawati, A, A, A, S., I Gusti, A, G, B., I Wayan, S. 2015. Isolasi dan identifikasi senyawa golongan flavonoid pada daun nangka (A. Heterophyllus) dan aktivitas antibakteri Staphylococus aureus. Jurnal Kimia 203-210

Hakim, A. 2010. Diversity of secondary metabolites from genus Artocarpus (Moraceae). Bioscience ISSN 20873940 Vol. 2 No. 3, 146-156

Hakim, A. dan a. wahab, J. 2011. Aktivitas antimalarial dan analisis senyawa metabolit sekunder kayu dan kulit batang Artocarpus odoratissimus Blanco. Jurnal Bahan Alam Indonesia ISSN 1412-2855 Vol. 7, No. 6

Hyene, K. 1987. Tumbuhan berguna Indonesia, Edisi 2, Badan Penelitian dan Pengembangan Kehutanan, Departemen Kehutanan (penerjemah). Jakarta: Yayasan Sarana Wana Jaya

Hsu, C. Ming-Huan, S. Jer-An, L GowChin, Y. and Song-Chwan, F. 2011. Cytotoxic effects of geranyl flavonoid derivates from the fruit of Artocarpus communisin SKHep-1 human hepatocellular carcinoma cells. Food Chemistry 127-134

Ko, H., Yi-Huang, L., Sheng-Zehn, Y., Shen-Jeu, W., and Chun-Nan, L. 2005. Cytotoxic Prenylflavonoids 
from Artocarpus elasticus. J. Nat.

Prod. Vol. 68, no. 11, 1692-1695

Raharjo, T. J. 2012. Kimia Hasil Alam. Pustaka Belajar

Risdian, C. Tjandwati, M. dan Puspa, D, $\mathrm{N}$, L. 2014. Isolasi siklokomunol dari daun sukun Artocarpus altilis (Parkinson) Fosberg serta aktivitasnya sebagai antikanker. JKTI, Vol. 16No. 2 : 82-86

Tantengco, O, A, G. dan Sonia, D, J. 2015. Cytotoxic activity of crude extracts and fractions from Premna odorata (Blanco), Artocarpus camansi (Blanco) and Grilicidia sepium (Jacq) against selected human cancer cell lines. Asian Pac J Trop Biomed 5 (12) 1037-1041

Tasmin, N., Erwin., Kusuma, W, irawan. 2014. Isolasi, identifikasi dan uji toksisitas senyawa flavonoid fraksi kloroform dari daun terap (Artocarpus odoratissimus blanco). Jurnal Kimia FMIPA Unmul ISSN 1693-5616 Vol. 12 No. 1

Weng, J, R., Chan, S, C., Lu, Y, H., Ko, H, H., Lin, C, N. 2006. Antiplatelet prenylflavonoids from Artocarpus communis. Phytochem 67: 824-829

Widyawaruyanti, A., Subehan, Kalauni, S, K., Awale, S. Nindatu, M. Zaini, N, C., Syafruddin, D., Asih, P, B, S., Tezuka, Y., Kadota, S. 2007. New prenylated flavones from Artocarpus champeden, and their antimalarial activity in vitro. $J$ Nat Med 61: 410-413 